\title{
Location Choice Model for distribution centers: for use in regional economic centers
}

Joselma Maria da Silva ${ }^{1}$, University of Pernambuco, Pernambuco, Brazil

Djalma Silva Guimarães Júnior², University of Pernambuco, Pernambuco, Brazil

Carlos Henrique Michels de Sant'Anna ${ }^{3}$, University of Pernambuco, Pernambuco, Brazil

\section{RESUMO}

Objetivo - Este artigo pretende propor um modelo de escolha locacional para instalação de centros de distribuição por meio da programação linear.

Desenho/ metodologia / abordagem - As modelagens de decisão locacional permitem aos tomadores de decisão selecionar entre diferentes localidades possíveis, as que melhor se adequam aos critérios estabelecidos. Para tanto, foi proposto um modelo de programação linear inteira mista (PLIM) a fim de identificar a localização mais eficiente para um centro de distribuição na região na Mata Norte do Estado de Pernambuco, Brasil.

Resultados - A utilização do PLIM permitiu identificar os fatores que corroboram para a minimização dos custos de transporte, que são significativos para a logística de distribuição, indicando uma localização que minimiza tais custos e gera maior eficiência na operação logística em uma região do interior do estado que se configura como centro econômico regional.

Originalidade / Valor - A maioria dos modelos de escolha locacional para centros de distribuição é construída em uma lógica de regiões densamente povoadas e grandes centros urbanos, o valor dessa pesquisa reside na tentativa de otimizar a eficiência das operações logísticas em regiões interioranas.

Palavras-chave - Decisão locacional. Programação linear. Logística. Centros de distribuição. Economia local.

\section{ABSTRACT}

Purpose - This paper aims to propose a location choice model to establish distribution centers using linear programming.

Design/methodology/approach - Locational choice models allow decision makers to select between different possible locations, based on the best fit of established criteria. For this, a Mixed-Integer Linear Programming model (MILP) was proposed to identify the most efficient location for a distribution center in the region in the Mata Norte of the State of Pernambuco, Brazil.

Findings - The MILP model allowed us to identify the factors that support transport cost minimization, which are significant for the distribution logistics, indicating a location that minimizes these costs and generates greater efficiency in the logistics in a region within the interior of the state, which is a regional economic center.

Originality/Value - Most location choice models for distribution centers are built on the logic of densely populated regions and large urban centers, the value of this study lies in its attempt to optimize the efficiency of logistics within inland regions.

Keywords - Locational decision. Linear programming. Logistics. Distribution centers. Local economy.

1.joselma.20@gmail.com, https://orcid.org/0000-0003-2793-8691; 2. Rua Amaro Maltês de Farias, Nazaré da Mata - PE, 55800-000, djalma.guimaraes@upe.br, https://orcid.org/0000-0002; 3. carlos.santanna@upe.br; https://orcid.org/0000-00020046-5225.

SILVA, J.M.; GUIMARAÊS JUNIOR, D.S.; SANT’ ANNA, C.H.M. Location Choice Model for distribution centers: for use in regional economic centers GEPROS. Gestão da Produção, Operações e Sistemas, v.16, nº 1, p. 54 - 71, 2021.

DOI: http://dx.doi.org/10.15675/gepros.v16i1.2418 


\section{INTRODUCTION}

Logistical activity plays a major role in economic and social development, given that it is responsible for ensuring trade between the various economic agents, and for supplying markets meeting the needs of consumers.

A competitive logistics sector is decisive for the economic growth of a region, since the increase in the efficiency of the distribution system leads to a decrease in transportation costs, which translates into a reduction in the final cost of products and is reflected in gains in competitiveness of companies and, consequently, for the economy of a region and country (LEAN et al., 2014).

The distribution logistics corresponds to the company-customer-consumer relationship, being responsible for the physical distribution of the finished product to the points of sale, ensuring that orders are delivered on time, accurate, complete and at the correct cost. (CHING, 2001). Distribution centers (CDs) play an important role in the context of the interior regions of any country by concentrating a wide range of items in one place, minimizing transport and storage costs while expanding the product mix available for the local markets (ULMER et al, 2011).

The decision-making problem involving distribution networks and CDs, consists of the best configuration for sending products / goods to the markets, when selecting the transport and storage structure network in order to satisfy the demand (SEGURA, et al., 2014). Proper planning of the distribution network is vital for the competitiveness of organizations and above all for the efficient supply of interior regions.

The proper location of a $\mathrm{CD}$ provides competitive advantages, and according to Da Cunha Reis et al. (2017) the main objectives of warehouse facility design are: to minimize costs and maximize the rate of order processing. In this context, analyzing models of installation of these centers in an interior region is strategic, since in Brazil the average growth of these cities and rural regions contributes to the increase of the Gross Domestic Product (GDP) in a proportion higher than the other regions (IPEA, 2008). The survey will consider the Region of Mata Norte Pernambucana, whose emerging economic center is of paramount importance for the State of Pernambuco, remaining traditional in the sugar and alcohol sector and more recently has diversified its productive capacity with the installation of an automotive and industrial hub. 
Given the above, the problem of this research is developed in order to investigate the characteristics of an optimal location of a CD through the mixed integer linear programming model (PLIM) and, thus, contributes to the making of managerial decision, insofar as it proposes a tool to aid locational decision in areas in expansion in the Brazilian economy, which historically have been marginal in the development of logistical projects, emphasizing that such regions have high potential for expanding markets and satisfaction of pent-up demands.

On the other hand, the application of PLIM modeling for locational choice in interior regions expands the scope of studies related to the theme, which traditionally focus on more mature and capillary economies and markets. Therefore, the research approach fills the literature gap by addressing the problem of locating CDs in geographical mesoregions that group municipalities with a population of less than 100 thousand inhabitants.

The research is divided into five sections. The first section corresponds to this introduction. The second section deals with the theoretical foundation, which aims to point out the contributions of the literature that support the development of the research; followed by the outline of the methodological procedures used in the research; the fourth section is dedicated to the presentation of the results of the PLIM model applied to the optimal choice of DC in interior regions; the work is concluded in section five with the presentation of the main conclusions evidenced in the research.

\section{THEORETICAL FOUNDATION}

\subsection{Facilities Location}

The changes that have been occurring over time, especially in the economic scenario, impose on organizations the need to develop competitive strategies, so that they can meet the growth in demand while providing entry into new markets previously unknown. Determining the location for an installation means finding an ideal environment to install an operational base to manufacture products or provide services, in order to obtain good management with competitive advantages over competitors (OLIVEIRA et al., 2015).

In this sense, the location of facilities is configured as a key element in the process of development and optimization of the service level, bringing with it the dynamics of the market, among the objectives to be achieved by the company. Ballou (2006) points out that the difficulties in the search for these strategic places, from a set of possible regions, are no 
longer involved only through Heuristic Methods and started to use quantitative methods.

According to Ritzman, Krajewski and Malhotra (2004, p.350), location choice can be defined as "the process that determines the geographic locations for the operations of a company". However, decision making regarding where to install the new facilities occurs through a systematic process, listing aspects that are not only operational, but the harmony between costs and benefits due to market knowledge, which is a key point in a logistics distribution network.

However, Casarotto Filho (2010) presents some other locational factors. These factors can be quantitative or qualitative. The most relevant quantitative factors according to this author are: i) those that make the location dependent on the inputs, especially when the production method requires bulky or heavy raw materials; ii) those that make the location dependent on exits, prioritizing the company's consumer market; iii) those that make the location dependent on the process, and; iv) taxes, legal factors and incentives.

Still within the locational decision process, Moreira (2015) emphasizes as determinants: localization of raw materials, being necessary to be close to them especially when the production process demands a large volume; availability of adequate labor, as without it, the activity may become unfeasible and the costs associated with employee transportation increased; availability of water and electricity, the adequate supply of which makes the production process more efficient; location of consumer markets, taking into account the distance from the main markets, in order to minimize transport costs and decrease the response time to customer orders; and finally, the community's attitudes towards the enterprise.

In the literature, several initiatives are presented to solve the problem of locational choice of CDs in supply networks. Georgiadis et al. (2011) and Sadjady and Davoudpour (2012), proposed mixed integer linear programming models to solve locational problems of supply chain networks. Longinidis and Georgiadis (2014) designed a mixed nonlinear programming model to integrate the supply of a supply chain with some advanced methods of financial management. Yolmen e Salehi (2015) proposed a mixed integer nonlinear model for the integrated problem of supply chain network design and assembly line balancing under uncertainty. Zhuge et al., (2016) proposes a stochastic programming model for the location of CDs with uncertain demands, in order to determine the appropriate production scale, as well as adapt the $\mathrm{CD}$ to fluctuations in retail. 


\subsection{Competitive advantage}

Seeking a sustainable and defensible competitive advantage has been the concern of every manager aware of the current market reality. Today, it is no longer believable that products can sell on their own, nor be sure that today's success will be guaranteed tomorrow (BUTTNER; MORANO, 2013). Successful companies either have a cost advantage, or have a value advantage, or a combination of both. Logistical management has the potential to help the organization in these two variables (CHRISTOPHER, 2007).

Such perspectives open space for discussion when thinking about a globalized market, in which corporate actions become more flexible, seeking alternatives to better position themselves in relation to competitors with objectivity, expanding their area of operation to "the peripheries" adding value in addition to meet customer needs.

Achieving these operational performance objectives generates competitive advantage for companies in production with quality, speed and responsiveness in delivery, reliability to meet assumed commitments, operational flexibility to serve customers and develop operations at the lowest possible cost.

\subsection{Distribution Logistics}

In the search for competitive advantages that increasingly guarantee them to act in a sustainable manner, companies are opting for direct purchase from distributors, to the detriment of intermediaries or wholesalers, whose function is to act as agents for the purchase and distribution of products need (BOWERSOX; CLOSS, 2001). In this context, distribution logistics acts as a key element in this process, due to the relevance of the constant flow of information and materials, transforming the reduction of waiting time into efficiency.

According to Silva (2006), the success and efficiency of distribution logistics also depends on the level of cooperation between the participating companies, since the constant and reliable flow of information is a determining factor in the management of the distribution process and essential for meeting the requirements of end customers. The performance of distribution networks involves the optimization of various decision criteria such as location, load allocation, inventory,etc. (SEGURA et al., 2014).

The organization's market vision is a determining factor for the success of a logistics distribution network, as it guides the organization in the search for efficiency in terms of 
logistics structure. As an example of this, there is the choice of distribution points, the strategic location for the company to expand and retain customers, which should be at the heart of the problem regarding the planning of distribution logistics..

\subsection{Linear Programming Model}

Decisions to locate distribution centers are influenced by macroeconomic, political, strategic, technological, competitive, logistical, operational and infrastructure factors (CHOPRA; MEINDL, 2016). Based on these principles, the linear programming model appears as a subsidy regarding the solution of problems related to allocation, distribution and transportation, evaluating efficiency while providing a reduction in operating costs.

In this sense, mathematical modeling is necessary, based on the principle that it is a quantitative analysis, whose structuring is focused on solving problems in which variables are presented, which can be expressed through linear equations and or inequalities (MOREIRA, 2015 ). In short, the decisions to be made are based on the articulation of the objectives to be achieved by the organization in both economic and structural terms, and in the understanding of a competitive approach in a dynamic market.

Thus, Corrar and Garcia (2001) present the following steps to be taken for the construction of the mathematical model: a) determine the decision variables b) establish the objective c) determine the basic relationships, especially restrictions d) calculate the optimal solution .

Within a market perspective, have mechanisms and strategies that can minimize costs by expanding the capacity to act.

\section{METHODOLOGICAL PROCEDURES}

\subsection{Search Ranking}

The research methodology adopted in this study can be classified as an applied research, according to quantitative approaches from the moment that the information will be transformed into numbers being subject to analysis and comparisons, and also qualitative through the description of the observed phenomena attributing the same meanings .

From the point of view of the objectives it is classified as descriptive which allows a holistic view through the observation, analysis and interpretation of the data collected with respect to the problem of location of facilities, as a competitive strategy and using 
mathematical modeling and simulation as a technical procedure . Modeling and simulation is a mainly quantitative research method, which should be used when it is desired to predict the effect of changes in the system or to evaluate its future performance or behavior (MARCONI; LAKATOS, 2010).

\subsection{Characteristics of the region}

The Mata Pernambucana mesoregion is one of five in the state of Pernambuco. It is formed by the union of 43 municipalities distributed in three microregions. It extends over an area of $8,738 \mathrm{~km}^{2}$, limited to the north with Paraíba, to the south with Alagoas, to the east with the Metropolitan Region of Recife and to the west with Agreste Pernambuco. It has an estimated population of 1,132,544 inhabitants. (PROJETOS DA ÂNCORA, 2018).

The municipalities of Nazaré da Mata, Carpina, Timbaúba, are part of this mesoregion and Goiana, which recently became part of the Metropolitan Region of Recife (RMR), are the cities in which the study was carried out. The city of Goiana stands out with the largest economy in the region, which in January 2018 became part of the RMR and counts on the Jeep automotive pole, in addition to the industrial complex of the Brazilian Hemodivirus and Biotechnology Company - HEMOBRÁS. It had an estimated population of 79,249 inhabitants in 2017 and a Gross Domestic Product per capita of R \$ 49,198.06 (IBGE, 2018).

The city of Carpina, in turn, stands out from the evolution of trade in the region of Mata Norte in Pernambuco, presenting the largest service infrastructure in the region. The city of Nazare da Mata is renowned for its activity in agriculture, especially in sugarcane monoculture, which employs a large part of the region's inhabitants and also has one of the largest poultry slaughterhouses in the State of Pernambuco (DESBRAVANDO, 2018 ). Another municipality with significant participation in the region's economy is Timbaúba, which stands out in the activities of the agricultural and commercial sector, since it is located in the vicinity of several other smaller cities in the region. (MFURAL, 2018).

\section{RESULTS}

\subsection{Mathematical Modeling}

The scope of the research has as its main objective the analysis of the development and allocation of new facilities, so that, to transpose this evaluation, the mathematical method PLIM will be proposed. However, the relevant aspect to be highlighted in the application of 
the mathematical model is the minimization of transportation costs by reducing the distance to be traveled between the CDs and the point of potential demand and or customers.

In this sense, the distribution network is designed from (I) a manufacturing point, CDs are considered a conditioning factor for optimizing the service level and J1, J2 and J3 as consumption points to be met in their total demand, through the competitiveness of the market.

However, in the current scenario, the distance to be covered during the distribution process, which comprises the manufacturing sector (I) and the points of consumption (J1, J2 and J3), are highlighted by the negative impacts on the costs of transportation when the distances to be covered (I - J1, I - J2, I - J3) justify the relevance of the study of location of $\mathrm{CD}$ installations as an instrument of efficiency and competitiveness, acting as an intermediary between the manufacturing sector and the demand points and or customers.

Table 1: distribution points / km: current scenario

\begin{tabular}{|c|c|c|c|c|c|}
\hline In & For & $\begin{array}{c}\text { J1 } \\
\text { (Nazaré da Mata) }\end{array}$ & $\begin{array}{c}\mathbf{J 2} \\
\text { (Goiana) }\end{array}$ & J3 (Timbaúba) & CDs (Carpina) \\
\hline \multirow{4}{*}{$\begin{array}{c}\text { I } \\
\text { (Recife) }\end{array}$} & 1 & 69,0 & & & \\
\hline & 2 & & 62,09 & & \\
\hline & 3 & & & 101,5 & \\
\hline & 4 & & & & 53,08 \\
\hline
\end{tabular}

Source: Own elaboration (2017). 
Table 2: Distribution points / km: proposed scenario by inserting the CD's Source: Own elaboration (2017)

\begin{tabular}{c|c|c|c|c}
$\begin{array}{c}\text { De } \\
\text { CD's }\end{array}$ & Para & J1 (Nazaré da Mata) & J2 (Goiana) & J3 (Timbaúba) \\
\cline { 2 - 5 } & 1 & 15,05 & & \\
\cline { 2 - 5 } 2 & & 54,09 & \\
& & & & \\
\cline { 2 - 5 } & & & & \\
& & & &
\end{tabular}

According to Tables 1 and 2, the decision to be taken is based on minimizing of transport costs based on the analysis of the two scenarios presented through the distances between the point of origin and the point of destination. In this sense, the scenario that was proposed, brings with it the insertion of CDs, making evident the reduction of time and transportation costs when the distance to be covered to meet the demand had been reduced considerably.

Figure 1: Graphical representation of distribution logistics, highlighting the determination of the proposed scenario. 


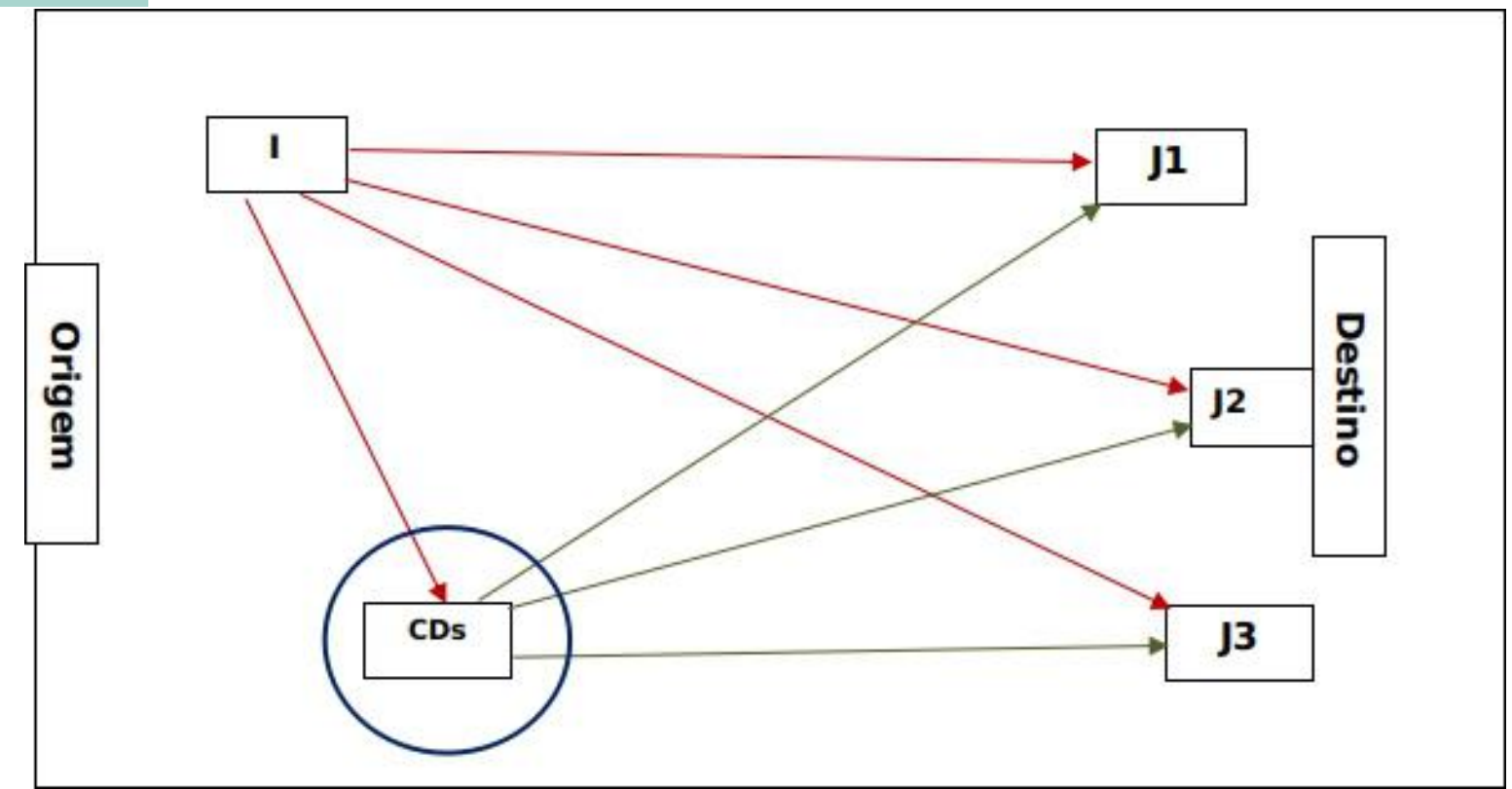

Source: Own elaboration (2017).

Following is the mathematical modeling, which describes the scenario considered feasible for future investments, highlighting the specifics of the problem to be experienced in this study, whose indexes are described below:

$\mathbf{D}-\mathrm{CDs}$

$\mathbf{J}$ - Customers (points of consumption)

$\mathbf{K}$ - Availability (minimum and maximum)

\section{Variables:}

Quantitative for Transport dj - the quantity to be transported from the Distribution Center (DC) to meet customer demand and or consumption points (J).

$\mathrm{Zd}$ - comprises the binary decision variable assuming a value of 1 when the DC's capacity matches the organization's competitive strategy and 0 when this expectation is not met.

\section{Purpose Function:}

Min $Z=\sum X d j 1+\sum X d j 2+\sum X d j 3$ (minimize the total cost of transportation by optimizing the distances to be covered in the distribution, highlighting the distribution center consumption points).

\section{Subject to the following restrictions:}

1. Demand restrictions for $\mathrm{J} 1$

$\sum \sum$ fluxo cd $\mathrm{j} \leq \mathrm{j} 1$

cd j1 
2. Demand restrictions for $\mathrm{J} 2$

$\sum \sum$ fluxo cd $\mathrm{j} \leq \mathrm{j} 2$

$\operatorname{cd~j} 2$

3. Demand restrictions for J3

$\sum \sum$ fluxo cd $\mathrm{j} \leq \mathrm{j} 3$

$\operatorname{cd~j3}$

4. Maximum availability of $\mathrm{CD}$

$\sum \sum$ fluxo $\mathrm{cd} \mathrm{j} \leq \mathrm{K}$ máx.

$\mathrm{cd} \mathrm{j}$

5. Minimum availability of $\mathrm{CD}$

$\sum \sum$ fluxo $\operatorname{cdj} \geq \mathrm{K}$ min.

$\mathrm{cd} \mathrm{j}$

\section{Binary}

Zd = 1, when CDs, they correspond to a competitive strategy;

$=0$, when CDs do not meet the needs of customers and or points of consumption.

6. Non-negativity restrictions

Flow cd j $\geq 0$

The presented modeling does not mean an end in itself, it opens space for discussion about the economic viability in which the installations are inserted, being seen in this research the competitive advantages when the effective distance between the performance points is highlighted, having the necessary tools for a small, medium or large scale analysis assisting in decision making.

The objective function corresponds to the sum of the necessary transport costs for each point of consumption to be served by the CDs, taking as a parameter the reduction of them through the strategy used in distribution, thus allowing a new configuration in transport logistics and consequently the reduction in costs, when the competitive strategy demands observation new parameters for localization.

With respect to restrictions, they act in order to determine a comparison imposing 
limits by means of the quantitative sum of products and or services to be demanded from the distribution point (CDs), designated as origin to destination (Customers), making clear the relevance of $\mathrm{CDs}$ as intermediaries from the moment that the reduction occurs and the possibility of meeting the demand efficiently.

\subsection{Development of the programming model}

Based on these data, the Municipality of Carpina presents the most favorable location for the installation of the distribution center, by supplying the Zona da Mata Norte and other surrounding regions more efficiently.

The results found through the application of the Solver Tool allow the conclusion that the proposed scenario in which it aims at the viability of the distribution process at the same time that it visualizes new fronts of action, especially in the aid of decision making. Such results are described in the subsequent specifications by generating the response report (Figure 2).

Figure 2: Response report generated in the application of the Solver Tool

\begin{tabular}{|c|c|c|c|c|c|}
\hline Maximize & & & & & \\
\hline Cell & Name & Original value & Final Value & & \\
\hline$\$ B \$ 13$ & Local demand X3 & 450 & 450 & & \\
\hline \multicolumn{6}{|l|}{ Variable Cells } \\
\hline Cell & Name & Original value & Final Value & Integer & \\
\hline$\$ B \$ 3$ & $x 1$ & 300 & 300 & Integer & \\
\hline$\$ B \$ 4$ & $x 2$ & 780 & 780 & Integer & \\
\hline$\$ B \$ 5$ & $x 3$ & 450 & 450 & Integer & \\
\hline \multicolumn{6}{|l|}{ Restrictions } \\
\hline Cell & Name & Cell value & Formula & Status & Slack \\
\hline$\$ B \$ 11$ & Local demand X1 & 300 & $\$ B \$ 11<=\$ D \$ 11$ & Association & 0 \\
\hline$\$ B \$ 12$ & Local demand X2 & 780 & $\$ B \$ 12<=\$ D \$ 12$ & Association & 0 \\
\hline$\$ B \$ 13$ & Local demand X3 & 450 & $\$ B \$ 13<=\$ D \$ 13$ & Association & 0 \\
\hline$\$ B \$ 14$ & Maximum CD availability & 1530 & $\$ B \$ 14<=\$ D \$ 14$ & non-association & 4590 \\
\hline$\$ B \$ 15$ & Maximum CD availability & 1530 & $\$ B \$ 15<=\$ D \$ 15$ & Association & - \\
\hline$\$ B \$ 16$ & & 300 & $\$ B \$ 16<=\$ D \$ 16$ & non-association & 300 \\
\hline$\$ B \$ 17$ & & 780 & $\$ B \$ 17<=\$ D \$ 17$ & non-association & 780 \\
\hline$\$ B \$ 18$ & & 450 & $\$ B \$ 18<=\$ D \$ 18$ & non-association & 450 \\
\hline \multicolumn{6}{|l|}{$\$ B \$ 3=$ integer } \\
\hline \multicolumn{6}{|l|}{$\$ B \$ 4=$ integer } \\
\hline$\$ B \$ 5=$ integer & & & & & \\
\hline
\end{tabular}

Source: Own elaboration (2017). 
Thus, in this report the viable solution for the optimization of distribution logistics was given, through the scenario that was proposed, in which it acts as a key element in the competitive strategy of the organization, highlighting for this the optimal value of the objective function (objective cell ), the decision variables (variable cells) and the determinations for the restrictions, presented in Table 3.

Table 3: Spreadsheet of estimated transport costs to meet the demand of the referred consumption points in the proposed scenario

Decision Variables

\begin{tabular}{c|c}
\hline$X 1$ & 300,00 \\
\hline$X 2$ & 780,00 \\
\hline$X 3$ & 450,00 \\
\hline Objective Function & $631,500,00$ \\
\hline Restrictions & $\leq 300,00$ \\
\hline Locality Demand X1 & $\leq 780,00$ \\
\hline Locality Demand X2 & $\leq 450,00$ \\
\hline Locality Demand X3 & $\leq 1.530,00$ \\
\hline Máx. CD Capacity & $\geq 1.530,00$ \\
\hline Min. CD Capacity & $\geq$ Not Negativity
\end{tabular}

Source: Own elaboration (2017).

With regard to the variables, the corresponding figures do not present contingencies, being the same presented in the original and final value, reaffirming the viability of the model being exposed. With regard to restrictions, the specification of non-association and association found in the conceptions of the availability of the CD can be observed, meaning that the capacity of the CD is presented dynamically. This fact can be observed in the Status field and in the Delay margin, the other non-associations and associations are complementary to the demands of the locations. Emphasizing that the viable solution was described by the solver tool. 


\section{DISCUSSION}

In this research, the application of mixed integer linear programming in the location of CD installations was approached, similarly to Georgiadis et al. (2011) and Sadjady and Davoudpour (2012), differentiating themselves from such authors when addressing this problem in interior regions, in view of the recent expansion in the number of CDs in the Zona da Mata Norte Pernambucana. To this end, the problem addressed refers to obtaining competitive advantage through the organizational strategy so that, its sphere of action could meet both the current demand and the entry into new markets.

With regard to the PLIM model, the indexes presented comprise the fundamental elements of location, that is, the links that serve as a basis to outline the strategy that may be used by the organization. The optimization of the service level, starting from the distribution point (CDs) to meet the demand, should be the minimization of transport costs determined in the objective function, without which it does not justify the location of new facilities in viable locations.

For the decision variables, the specificities shown in Figure 1 were adopted, by canceling point (I), where the crossing between the structure of the DC and the points of consumption $(\mathrm{J})$ occurs under the relevance of the demand to be met, and thus seeking to obtain the shortest possible distance from the insertion of the $\mathrm{CD}$, acting actively in the distribution logistics. The analysis refers to the importance of location studies from a strategic point of view through planning, from the moment that the binary variable establishes the viability relationship. As highlighted by Segura et al., (2014), to ensure the best performance of a distribution network, it is necessary to optimize the decision criteria.

Another point that draws attention in the modeling presented is that it is centered on restrictions, which clearly and objectively reflect the limitations imposed, so that in fact the minimization of transportation costs occurs, making evident the relevance of CDs as a sine qua non condition for the combinations and or comparisons made. It should be noted that for the analysis carried out, other methodologies can also be used, according to the parameters that will be taken as a basis for future studies.

As a conclusive analysis instrument of the study carried out, it is necessary to understand the feasibility not only from a structural point of view, but also an economic one, as well as the confirmation that such conceptions are guiding elements to assist in decision 
making, where the subsidies used will serve as a basis for deepening the theme addressed in a clear and objective way.

\section{CONCLUSION}

The present study aimed to analyze the relevant aspects in the development and allocation of new facilities in interior regions, highlighting the competitive advantages by minimizing operating costs, thus adding value to the product and or service offered. In this sense, the PLIM model and later the Solver Tool were used as subsidies, the latter for the feasibility and optimization of the proposed model, with the aim that the said objective was achieved around the main points used as guidelines. Within the scope of possible locations, the city of Carpina presented more favorable conditions for the installation of the CD.

The survey results provide support resources for locational decision making for CDs in areas in recent expansion in the Brazilian economy, which have a high potential for expanding markets and satisfying unmet demands. Given the size of such markets, modeling can also be useful for medium and small businesses that postulate investment in this niche.

In this way, the methodology was developed adopting the analysis criteria previously established from the proposal of a new conjuncture through the observation of the current scenario presented, and in a practical way the description of the mathematical modeling, thus evidencing the relevance of the distribution logistics in the middle to the location perspective, through the variables that have been proposed. However, the structure adopted for the configuration of mathematical modeling is focused on specific aspects, such as the reduction in mileage corresponding to the displacement between the points analyzed, which will consequently minimize transport costs.

Therefore, the proposed study achieved its objectives by applying the PLIM model, establishing relevant criteria in the evaluation of the location choice of a $\mathrm{CD}$, within the considered region, the city of Carpina-PE. The expansion of the model presented when considering other factors that may influence the location choice are perspectives to be developed, making the model applicable to new problems related to logistics and its numerous applications, thus facilitating knowledge and understanding, especially of how to proceed with regard to location of new facilities.

On the other hand, the application of PLIM modeling for locational choice in inland 
regions broadens the scope of studies related to the theme, which traditionally focus on more mature and capillary economies and markets. Therefore, the research approach fills the literature gap by addressing the problem of DC location in geographical mesoregions that group municipalities with a population of less than 100 thousand inhabitants.

\section{References}

BALLOU, R. H.; Gerenciamento da cadeia de suprimentos: planejamento, organização e logística empresarial. $5^{\mathrm{a}}$ ed. Porto Alegre: Bookmann, 2006.

BOWERSOX, D. J.; CLOSS, D. J..Logística empresarial: o processo de integração da cadeia de suprimentos. São Paulo: Atlas, 2001.

BUTTNER, A.; MORANO, R. S. Vantagem competitiva através do Planejamento Estratégico: avaliação de firmas brasileiras de autopeças. GEPROS. Gestão da Produção, Operações e Sistemas, v. 3, p. 25-37, 2013.

CASAROTTO FILHO, N. Elaboração de projetos empresariais: análise estratégica, estudo de viabilidade e plano de negócio. São Paulo: Atlas, 2010.

CHING, H. Y. Gestão de Estoques na Cadeia de Logística Integrada - Supply Chain. 2.ed. São Paulo: Atlas, 2001.

CHOPRA, S.; MEINDL, P. Gerenciamento da Cadeia de Suprimentos: estratégia, planejamento e operações: São Paulo: Pearson, 2016.

CHRISTOPHER, M. Logística e Gerenciamento da Cadeia de Suprimentos: criando redes que agregam valor. São Paulo: Thomson Learning, 2007.

CORRAR, L.J.; GARCIA, E. A. R.; Programação linear: uma aplicação à contabilidade de custos no processo de tomada de decisão. Congresso Internacional de Custos, v. 7, 2001.

DA CUNHA REIS, A et al. Warehouse design: a systematic literature review. Brazilian Journal of Operations e Production Management, v. 14, n. 4, p. 542-555, 2017.

DESBRAVANDO, Nazaré da Mata. Disponível em http://desbravandopernambuco.blogspot.com/2013/03/nazare-da-mata.html. Acesso em $01 \mathrm{de}$ Jun de 2018.

GOVERNO DE CARPINA, Nossa Cidade. Disponível em <https://www.carpina.pe.gov.br/historico>. Acesso em 14 de Mai 2018.

GEORGIADIS, M. C.; TSIAKIS, P., LONGINIDIS, P.; SOFIOGLOU, M. K. Optimal design of supply chain networks under uncertain transient demand variations. Omega, n. 39, p. 254- 
$272,2011$.

IBGE - INSTITUTO BRASILEIRO DE GEOGRAFIA E ESTATÍSTICA. Pernambuco :Goiana..Disponível em: <https://cidades.ibge.gov.br/brasil/pe/goiana/panorama> Acesso em 13 de Jun. 2018.

IPEA - INSTITUTO DE PESQUISA ECONÔMICA APLICADA. Disponível em: http://www.redbcm.com.br/arquivos/bibliografia/pesquisa\%20ipea.pdf Acesso em 10 de Jun. 2018.

LEAN, H.H.; HUANG, W.; HONG, J. Logistics and economic development: Experience from China. Transport Policy, v. 32, p. 96-104, 2014.

LONGINIDIS, P.; GEORGIADIS, M. C. Integration of sale and leaseback in the optimal design of supply chain networks. Omega, v. 47, p. 73-89, 2014.

MARCONI, M. D. A.; LAKATOS, M. Fundamentos da metodologia científica. $7^{\circ}$ ed. São Paulo: Atlas, 2010.

MFRURAL, Timbaúba $\quad-\quad$ Pernambuco. Disponível em https://www.mfrural.com.br/mobile/cidade/timbaubape.aspx> Acesso em 13 de Mai 2018.

MOREIRA, D. AUGUSTO. Administração da Produção e Operações. 2.ed. Cengage Learning,2015.

Learning, 2015.

Pesquisa Operacional: curso introdutório. São Paulo: Cengage

OLIVEIRA, C. M. G.; CARMO, B. B. T.; MOREIRA, M. E. P. Alocação de postos de observação da polícia militar em uma cidade de médio porte: uma abordagem multicritério. GEPROS. Gestão da Produção, Operações e Sistemas. v. 3, p. 139-158, 2015.

PROJETOS DA ÂNCORA. A zona da Mata de Pernambuco. Disponível em: <http://www.ancora.org.br/textos/011_jansen-mafra.htmll>Acesso em: 18 Jul. 2015.

RITZMAN, L.; KRAJEWSKI, L.; MALHOTRA, M.;Administração da produção e operações. São Paulo. Prentice Hall, 350p,2004.

SADJADY, H.; DAVOUDPOUR, H. Two-echelon, multi-commodity supply chain network design with mode selection, lead-times and inventory costs. Computers \& Operations Research, v.39, p. 1345-1354, 2012.

SEGURA, E.; CARMONA-BENITEZ, R.F.; LOZANO, A. Dynamic location of distribution centres, a real case study. Transportation Research Procedia, v.3, p. 547 - 554, 2014.

SILVA, E. N. Centralização da distribuição e custos de transporte: estudo de caso da AMBEV. 2006. 94 f. Dissertação (Mestrado em Engenharia de Transportes) - Coordenação dos Programas de Pós-Graduação de Engenharia, Universidade Federal do Rio de Janeiro, Rio 
de Janeiro, 2006.

ULMER, J.S.; BELAUD, J.P.; LE LANN, J.M. Towards a pivotal-based approach for business process alignment. International Journal of Computer Integrated Manufacturing, v. 24, n. 11, p. 1010-1021, 2011.

YOLMEH, A.; SALEHI, N. An outer approximation method for an integration of supply chain network designing and assembly line balancing under uncertainty. Computers and Industrial Engineering, v. 83, p. 297-306, 2015.

ZHUGE, D.; YU, S.; ZHEN, L.; WANG, W. Multi-Period Distribution Center Location and Scale Decision in Supply Chain Network. Computers and Industrial Engineering, 2016. doi: http://dx.doi.org/10.1016/j.cie.2016.09.001. 